\title{
Selected problems with boron determination in water treatment processes. Part I: comparison of the reference methods for ICP-MS and ICP-OES determinations
}

\author{
Ewa Kmiecik $^{1}$ • Barbara Tomaszewska ${ }^{1,2}$ - Katarzyna Wątor ${ }^{1} \cdot$ Michał Bodzek $^{3,4}$
}

Received: 27 June 2015 / Accepted: 19 February 2016 / Published online: 4 March 2016

(C) The Author(s) 2016. This article is published with open access at Springerlink.com

\begin{abstract}
The aim of the study was to compare the two reference methods for the determination of boron in water samples and further assess the impact of the method of preparation of samples for analysis on the results obtained. Samples were collected during different desalination processes, ultrafiltration and the double reverse osmosis system, connected in series. From each point, samples were prepared in four different ways: the first was filtered (through a membrane filter of $0.45 \mu \mathrm{m}$ ) and acidified (using $1 \mathrm{~mL}$ ultrapure nitric acid for each $100 \mathrm{~mL}$ of samples) (FA), the second was unfiltered and not acidified (UFNA), the third was filtered but not acidified (FNA), and finally, the fourth was unfiltered but acidified (UFA). All samples were analysed using two analytical
\end{abstract}

Responsible editor: Céline Guéguen

Barbara Tomaszewska

barbara.tomaszewska@agh.edu.pl; b.tomaszewska@meeri.pl

Ewa Kmiecik

ewa.kmiecik@agh.edu.pl

Katarzyna Wątor

katarzyna.wator@agh.edu.pl

Michał Bodzek

michal.bodzek@polsl.pl

1 AGH University of Science and Technology, Faculty of Geology, Geophysics and Environmental Protection, Mickiewicza $30 \mathrm{Av}$, 30-059 Kraków, Poland

2 Mineral and Energy Economy Research Institute, Polish Academy of Sciences, Wybickiego 7, 31-261 Kraków, Poland

3 Silesian University of Technology, Institute of Water and Wastewater Engineering, Konarskiego 18, 44-100 Gliwice, Poland

4 Institute of Environmental Engineering of the Polish Academy of Sciences, M. Curie-Skłodowskiej 34, 41-819 Zabrze, Poland methods: inductively coupled plasma mass spectrometry (ICP-MS) and inductively coupled plasma optical emission spectrometry (ICP-OES). The results obtained were compared and correlated, and the differences between them were studied. The results show that there are statistically significant differences between the concentrations obtained using the ICP-MS and ICP-OES techniques regardless of the methods of sampling preparation (sample filtration and preservation). Finally, both the ICP-MS and ICP-OES methods can be used for determination of the boron concentration in water. The differences in the boron concentrations obtained using these two methods can be caused by several high-level concentrations in selected whole-water digestates and some matrix effects. Higher concentrations of iron (from 1 to $20 \mathrm{mg} / \mathrm{L}$ ) than chromium $(0.02-1 \mathrm{mg} / \mathrm{L})$ in the samples analysed can influence boron determination. When iron concentrations are high, we can observe the emission spectrum as a double joined and overlapping peak.

Keywords Boron - Analytical determination - Desalination . Geothermal water $\cdot$ Reverse osmosis

\section{Introduction}

Borates are widely found in nature, and they are present in oceans, sedimentary rocks, soil, coal and shale. Naturally occurring boron is found in groundwater, primarily as a result of leaching from rocks and soils that contain borates and borosilicates. Boron is detected in surface water and groundwater in various locations around the world, including sea and river waters, where it mainly occurs in the form of boric acid.

Boron compounds are also used during manufacturing processes, e.g. glass production, fibreglass, borosilicate glass, agricultural fertilisers and herbicides, laundry bleach, soaps and 
detergents, flame retardants and many other processes (Dill 2010). These compounds are often encountered in natural and waste waters where their concentration may reach tens and hundreds of milligrams per $1 \mathrm{dm}^{3}$ (Öner et al. 2011). Hence, the borate contents of surface and groundwater can be increased as a result of wastewater discharges (WHO 2011), especially from municipal (Motyka et al. 2005; Tomaszewska 2009), power plant (Tomaszewska 2009) or chemical landfill leachates (Malina 2004; Turek et al. 2007; Witkowski et al. 2008). As a result, boron is a commonly known contaminant of drinking water that affects the reproductive ability of living organisms.

Therefore, there exists the need to remove this element from the aqueous environment. Actually, many materials have been tested for this purpose including fly ash, zeolite and active carbons (Polat et al. 2004; Yüksel and Yürüm 2010). Zeolites seem to be promising materials, which, due to their ion-exchange properties and molecular sieve, have already been used in other fields of engineering and environmental protection, including removing heavy metals and ammonium ions from waste water or treating mine water with radioactive elements (Franus and Wdowin 2010; Liu et al. 2010; Niu et al. 2012; Merrikhpour and Jalali 2013; Chałupnik et al. 2013; Franus et al. 2014). A process that is more and more frequently used in the synthesis of zeolites is the treatment of fly ash with sodium hydroxide (Querol et al. 2001; Franus et al. 2014; Wdowin et al. 2014).

The level of boron concentration in drinking water varies widely and depends on the source of the drinking water, but for most of the world, the range is judged to be between 0.1 and $0.3 \mathrm{mg} / \mathrm{L}$ (Öner et al. 2011). In seawater, the boron concentration ranges from 0.5 to $9.6 \mathrm{mg} / \mathrm{L}$, an average value is found between $4.5 \mathrm{ppm}$ and $4.6 \mathrm{mg} / \mathrm{L}$ (Woods 1994; Farhat et al. 2013; Kabay et al. 2010). A high boron concentration is also a common feature of geothermal water sources (Dill 2010; Bundschuh et al. 2013; Tomaszewska and Szczepański 2014; Tomaszewska et al. 2014), especially when TDS is greater than $1 \mathrm{~g} / \mathrm{L}$ (Tomaszewska and Bodzek 2013a).

Due to its interaction with the environment, the boron concentration in drinking water is strictly controlled according to the WHO (up to $2.4 \mathrm{mg} / \mathrm{L}$ ) and European Union regulations (up to $1.0 \mathrm{mg} / \mathrm{L}$ ). In the case of water discharged to the environment, the boron level has to be limited to $1.0 \mathrm{mg} / \mathrm{L}$ (Polish government regulations). The World Health Organization had for many years recommended that the limits of boron concentration in drinking water be $0.5 \mathrm{mg} / \mathrm{L}$. The new guideline value is based on a human health perspective (WHO 2011), which was revised by the WHO Drinking-Water Quality Committee, acting on reports from the latest studies published in the USA (WHO 2011).

In many parts of the world, the presence of boron prevents the direct use of water for irrigation or as potable water and causes chemical pollution and environmental problems in ground and surface waters (Dill 2010). Boron is also an essential micronutrient for plants, but the concentration level required for optimum growth differs between plant species. In effect, there is a narrow margin between boron deficiency and toxicity in some plants (Kot 2009; Yavuz et al. 2013; Wolska and Bryjak 2013; Tomaszewska and Bodzek 2013a, b; Bodzek 2015). For many reverse osmosis (RO) plants producing drinking water from seawater or brackish water, it is challenging to reduce boron concentrations down to the stringent limits specified in the new regulations. The boron problem is more critical in many geothermal waters since they have higher boron concentrations than those in seawater.

On the other hand, it has been proved that boron is an essential element in the human diet; however, its specific biochemical function has not yet been identified (WHO 2011; Kabay et al. 2010). Between the middle of nineteenth century and the beginning of the twentieth century, boron compounds were used for treating various medical conditions including epilepsy, malaria, urinary tract infections and exudative pleuritis (EPA 2008). Culver and Hubbard (1996) report on early cases of boron treatment for epilepsy and on dose values ranging from 2.5 to $24.8 \mathrm{mg} \mathrm{B} / \mathrm{kg}$-day being prescribed for many years (Culver and Hubbard 1996). Overall, more than half of the average total exposure to boron comes from the diet. Previous studies have concluded that boron is important in the metabolism and the utilisation of calcium for the human bone structure (Mr and Samman 1993). Other benefits of boron include the improvement of brain function, the psychomotor response and the response to oestrogen injections in postmenopausal female patients. A crucial role of boron in keeping bones and joints healthy has also been described, and it has been effective in treating various forms of arthritis (Newnham 1994; Kabay et al. 2010). The guidance presented by WHO (2011) claims that short- and long-term exposure of the breathing system (exposure of respiratory paths, especially the pharynx) to boric acid or borax in laboratory animals has demonstrated that the male reproductive tract is a consistent target of toxicity (WHO 2011). Testicular lesions have been observed in rats, mice and dogs that were given boric acid or borax in food or drinking water. Developmental toxicity has been demonstrated experimentally in rats, mice and rabbits. Negative results in a large number of mutagenicity assays indicate that boric acid and borax are not genotoxic. In longterm studies in mice and rats, boric acid and borax caused no increase in tumour incidence (WHO 2011).

In that context, assessment of water quality and the analytical precision of boron determination plays a special role in the treatment of sea, ocean or geothermal water. It indeed determines the proper selection of the treatment process, which allows for the effective reduction of boron concentration to the level specified in the relevant legislation. The detection and quantification of boron and its stable isotopes has been conducted using several different techniques reported in the literature (Sah and Brown 1997; Witczak et al. 2007; Kot 
2009; Witczak et al. 2013; Farhat et al. 2013). These techniques are presented in Table 1.

This manuscript presents two plasma based methods mentioned in Table 1. The ICP methods are often used for boron determination in water samples. In this method, samples containing boron compounds are atomised into elemental $\mathrm{B}$ and ionised into $\mathrm{B}^{+}$cations. In these forms, boron is analysed using different types of detector (Farhat et al. 2013). The most popular are inductively coupled plasma optical emission spectrometry (ICP-OES) and inductively coupled plasma mass spectrometry (ICP-MS). Both ICP-MS and ICP-OES methods are published in the appropriate standards PN-EN ISO 11885:2009 and PNEN ISO 17294-1:2007 and provide the possibility of analysing boron concentration over a wide range. The problems with boron analysis using these two methods are widely described in the literature (Dulski 1996; Al-Ammar et al. 1999; Aggerwal et al. 2003; Parks 2005; Eppich et al. 2011). The biggest problem is memory but sample matrix composition could also affect the bias and variability of the ICP-MS method. Research provided by Garbarino (1999) shows that matrix composition can suppress the ionisation efficiency of the plasma and result in negatively biased results from analysis. This effect can be significant for whole-water matrices because of the level of dissolved solid concentrations. Analysis of water samples performed by Garbarino (2000) indicates that differences in boron concentrations obtained by the ICP-MS and ICP-OES methods are significant, and they are caused by several high-level concentrations in selected whole-water digestates.

In the ICP-OES method, the boron concentration is detected on the basis of the value of the electromagnetic radiation emitted by excited B atoms. Typically monitored wavelengths characteristic for boron are 182.52, 249.678 and $249.773 \mathrm{~nm}$. Detection limits vary from 0.005 to $0.01 \mathrm{mg} / \mathrm{L}$. The common interferences are from iron and chromium (van de Wiel 2003).

The ICP-MS methods allow the analysis of two boron isotopes: ${ }^{10} \mathrm{~B}$ and ${ }^{11} \mathrm{~B}$. Concentrations of boron isotopes are determined on the basis of their mass-to-charge $(\mathrm{m} / \mathrm{z})$ ratio. The detection limit is $0.01 \mathrm{mg} / \mathrm{L}$. There are no spectroscopic interferences (van de Wiel 2003). The very important factors in boron determination with the ICP-MS method are sample matrices, memory effects and some instrument parameters (Sah and Brown 1998).

The most common method of sample preparation for ICP is filtration and acidification with a proportion of $1 \mathrm{~mL}$ of concentrated $\mathrm{HNO}_{3}$ per $100 \mathrm{~mL}$ of water sample. So, in this situation, only dissolved boron is analysed.

\section{Objectives}

Proper collection of water samples, fixation and transport to the laboratory are especially important matters in water sampling when choosing the appropriate analytical procedure. The main objective of this study was to determine the precision of analytical determination of boron in water samples which have been taken during geothermal water treatment processes. The paper presents a comparison of the ICP-MS and ICP-OES reference method determinations related to boron quantification during water treatment.
Table 1 Principles of the major boron analysis techniques

\begin{tabular}{|c|c|c|}
\hline \multicolumn{2}{|l|}{ Technique } & \multirow{2}{*}{$\begin{array}{l}\text { Principles of the technique } \\
\text { Formation of free atoms of boron then monitors the wavelength } \\
\text { emissions from boron excited atoms at its corresponding } \\
\text { wavelengths }\end{array}$} \\
\hline Plasma based & ICP-OES & \\
\hline & ICP-MS & $\begin{array}{l}\text { Ionizing boron into } \mathrm{B}^{+} \text {ions, then measuring } \mathrm{B} \text { isotopes } \\
\text { abundance based on their mass-to-charge ratio }(\mathrm{m} / \mathrm{z} 10 \\
\text { and 11) }\end{array}$ \\
\hline \multirow[t]{2}{*}{ TIMS } & PTIMS & $\begin{array}{l}\text { Converting boron into alkali or metal metaborate cations } \\
\text { such as } \mathrm{Na}_{2} \mathrm{BO}_{2}^{+}(\mathrm{m} / \mathrm{z} 88 \text { and } 89) \text { and } \mathrm{Cs}_{2} \mathrm{BO}_{2}^{+} \\
(\mathrm{m} / \mathrm{z} 308 \text { and 309) then measuring their corresponding } \\
m / z \text { ratio }\end{array}$ \\
\hline & NTIMS & $\begin{array}{l}\text { Converting boron into metaborate anions of } \mathrm{BO}_{2}^{-}(\mathrm{m} / z 42 \\
\text { and } 43) \text { then measuring their corresponding } \mathrm{m} / \mathrm{z} \text { ratio }\end{array}$ \\
\hline \multirow[t]{2}{*}{ Non-MS-based } & Spectrophotometry & $\begin{array}{l}\text { Adding specific reagents to the boron samples for colour } \\
\text { development, then measuring the absorbance at wavelengths, } \\
\text { respective of the reagent (e.g. curcumin or carmine } \\
\text { method-Standard methods, 2012) }\end{array}$ \\
\hline & Nuclear & $\begin{array}{l}\text { Bombarding boron with neutrons causing the production of } \\
\text { a-particles and g-particles that are monitored to measure } \\
{ }^{10} \mathrm{~B} \text { isotope abundance }\end{array}$ \\
\hline
\end{tabular}

After Farhat et al. (2013)

$\mathrm{m} / \mathrm{z}$ mass-to-charge ratio 


\section{Materials and methods}

A total of 56 samples were collected during different desalination processes including ultrafiltration and double reverse osmosis systems connected in series (Tomaszewska and Bodzek 2013b). Four samples from each point in the treatment system were taken for determination using ICP-OES and ICPMS methods according to the requirements of the PN-ISO 5667-11:2004 standard. Samples were prepared in different ways, using four sampling protocols:

1. Fourteen samples were filtered (through a membrane filter of $0.45 \mu \mathrm{m}$ ) and acidified (using $1 \mathrm{~mL}$ ultrapure nitric acid for each $100 \mathrm{~mL}$ of sample) (FA)

2. Fourteen samples were unfiltered and not acidified (UFNA)

3. Fourteensamples were filtered but not acidified (FNA)

4. Fourteen samples were unfiltered but acidified (UFA)

Samples were collected in polyethylene bottles. Then, samples were cooled and sent immediately to the laboratory where only plastic bottles and probes were used to avoid sample contamination, for example from borosilicate glass.

To treat how big an influence filtration and acidification has on the boron concentration in water samples, the authors also compare the results obtained for certified samples with known boron concentration. The analysis was performed at three concentration levels and repeated five times:

- $2.5 \mathrm{mg} \mathrm{B} / \mathrm{L}$

- $1.0 \mathrm{mg} \mathrm{B} / \mathrm{L}$

- $0.5 \mathrm{mg} \mathrm{B} / \mathrm{L}$

The samples were analysed using ICP-OES (Optima 7300DV - PN-EN ISO 11885:2009) and ICP-MS methods (ELAN 6100 - PN-EN ISO 17294-1:2007, PN-EN ISO 17294-2:2006). The certified ranges for the boron determination, declared by the laboratory, are as follows: for ICP-MS, 0.01-100 mg/L; for ICP-OES, $0.1-100 \mathrm{mg} / \mathrm{L}$ (PCA certificate, no $\mathrm{AB} 1050$ ), and the uncertainty of boron determination is lower than $20 \%$ with both methods.

The Optima 7300DV Inductively Coupled Plasma Optical Emission Spectrometer (ICP-OES) is a dual detector system. The UV detector covers an extended ultraviolet wavelength range from 165 to $403 \mathrm{~nm}$ whereas the VIS detector covers the visible wavelength range from 404 to $782 \mathrm{~nm}$. In dual-view instruments plasma can be viewed either axially or radially. The Sample Introduction Compartment with Quick Change Torch Module characteristics and some apparatus parameters are shown in Table 2.

The ELAN 6100 Inductively Coupled Plasma Mass Spectrometer (ICP-MS) has an original dual-stage detection system with a discrete dynode electron multiplier. The Sample
Table 2 Sample introduction compartment characteristics and some ICP-OES spectrometer parameters for boron determination in water samples

\begin{tabular}{ll}
\hline $\begin{array}{l}\text { Sample introduction } \\
\text { compartment/parameter }\end{array}$ & Type/value \\
\hline Torch & $\begin{array}{c}\text { Standard alumina injector with a } \\
2.0-\mathrm{mm} \text { inner diameter } \\
\text { Double-pass Scott-type }\end{array}$ \\
Spray chamber & The Gem Tip cross flow, pneumatic \\
Nebuliser & $40 \mathrm{MHz}$ \\
RF frequency & $1300 \mathrm{~W}$ \\
RF generator & $15 \mathrm{~L} / \mathrm{min}$ \\
Plasma flow & $0.2 \mathrm{~L} / \mathrm{min}$ \\
Auxiliary flow & $0.8 \mathrm{~L} / \mathrm{min}$ \\
nebuliser flow & $1.5 \mathrm{~mL} / \mathrm{min}$ \\
Sample flow rate & $30 \mathrm{~s}$ \\
Equilibration time & $249.678 \mathrm{~nm}$ \\
Wavelength & $\mathrm{Fe}, \mathrm{Cr}$ \\
Interferences & 3 \\
Replicates & \\
\hline
\end{tabular}

Introduction Compartment characteristics and some apparatus parameters are shown in Table 3.

All analyses were performed in the certified Hydrogeochemical Laboratory of the Hydrogeology and Engineering Geology Department of the University of Science and Technology in Cracow (PCA certificate, no AB 1050). The laboratory takes part in proficiency testing and interlaboratory comparisons obtaining satisfactory results (Zscore absolute value lower than 2). In this laboratory, an internal quality control system is also implemented.

Table 3 Sample introduction compartment characteristics and some ICP-MS spectrometer parameters for boron determination in water samples

\begin{tabular}{ll}
\hline Sample introduction compartment/parameter & Type/value \\
\hline Torch & Quartz \\
Spray chamber & Double-pass Scott-type \\
Nebuliser & Cross flow \\
RF frequency & $40.16 \mathrm{MHz}$ \\
RF generator & $1050 \mathrm{~W}$ \\
Plasma flow & $15 \mathrm{~L} / \mathrm{min}$ \\
Auxiliary flow & $1.5 \mathrm{~L} / \mathrm{min}$ \\
Nebuliser flow & $0.93 \mathrm{~L} / \mathrm{min}$ \\
Sample flow rate & $1.5 \mathrm{~mL} / \mathrm{min}$ \\
Monitored isotopes & ${ }^{11} \mathrm{~B}$ \\
Interferences & $\mathrm{No}$ interferences \\
Internal standard & ${ }^{89} \mathrm{Y}$ \\
Equilibration time & $400-3000 \mathrm{~ms}$ \\
Replicates & 3 \\
\hline
\end{tabular}


Table 4 Boron concentration in the water samples analysed (descriptive statistics $[\mathrm{mg} / \mathrm{L}]$ )

\begin{tabular}{lllll}
\hline Sampling protocol & Range & Minimum & Maximum & Mean \\
\hline $\begin{array}{l}\text { ICP-MS method } \\
\text { FA }\end{array}$ & 3.01 & 0.18 & 3.19 & 1.19 \\
FNA & 3.58 & 0.18 & 3.76 & 1.28 \\
UFA & 3.12 & 0.17 & 3.29 & 1.18 \\
$\quad$ UFNA & 3.68 & 0.17 & 3.85 & 1.29 \\
ICP-OES method & & & & \\
FA & 6.46 & 0.29 & 6.75 & 2.04 \\
$\quad$ FNA & 6.34 & 0.25 & 6.59 & 2.00 \\
$\quad$ UFA & 6.53 & 0.26 & 6.79 & 2.04 \\
UFNA & 6.53 & 0.24 & 6.77 & 2.02 \\
\hline
\end{tabular}

$F A$ filtered but acidified, $F N A$ filtered but not acidified, $U F A$ unfiltered but acidified, UFNA unfiltered but not acidified

\section{Results and discussion}

The most commonly used methods of boron determination in Polish laboratories are ICP-MS and ICP-OES which form the methods of reference (Witczak et al. 2013). ICP is a type of plasma source formed from electric currents that are caused by electromagnetic induction in a rarefied gas such as argon. Samples are usually prepared in the aqueous phase using steps involving extraction and purification and are then introduced into the plasma of the instrument via a nebuliser and spray chamber (Sah and Brown 1997; Kmiecik and Podgórni 2009; Kmiecik 2011). ICP-OES, earlier known as ICP atomic emission spectroscopy (ICP-AES), is one type of ICP that detects electromagnetic radiation emitted from energised atoms and ions produced by the plasma source in which the wavelength of the radiation emitted is characteristic of an element (Sah and Brown 1997). The coupling of ICP with a mass spectral detector (ICP-MS) allows boron determination with the simultaneous measurement of boron concentration and its isotopic abundance $\left({ }^{11} \mathrm{~B}\right.$ and $\left.{ }^{10} \mathrm{~B}\right)$ leading to lower detection limits and higher sensitivity (Sah and Brown 1997; Farhat et al. 2013). Instead of monitoring the wavelength-specific emissions of the energised ions as in ICP-OES, the ICP-MS method measures the ions based on their mass-to charge $(\mathrm{m} / \mathrm{z})$ ratio; thus, it simultaneously measures boron concentration and its stable isotope abundance.

The results of the analysis for the control samples, blank samples and certified reference materials prove that the
Fig. 1 Boron concentrations in the water samples analysedcomparison of four sampling protocols and two methods of analysis
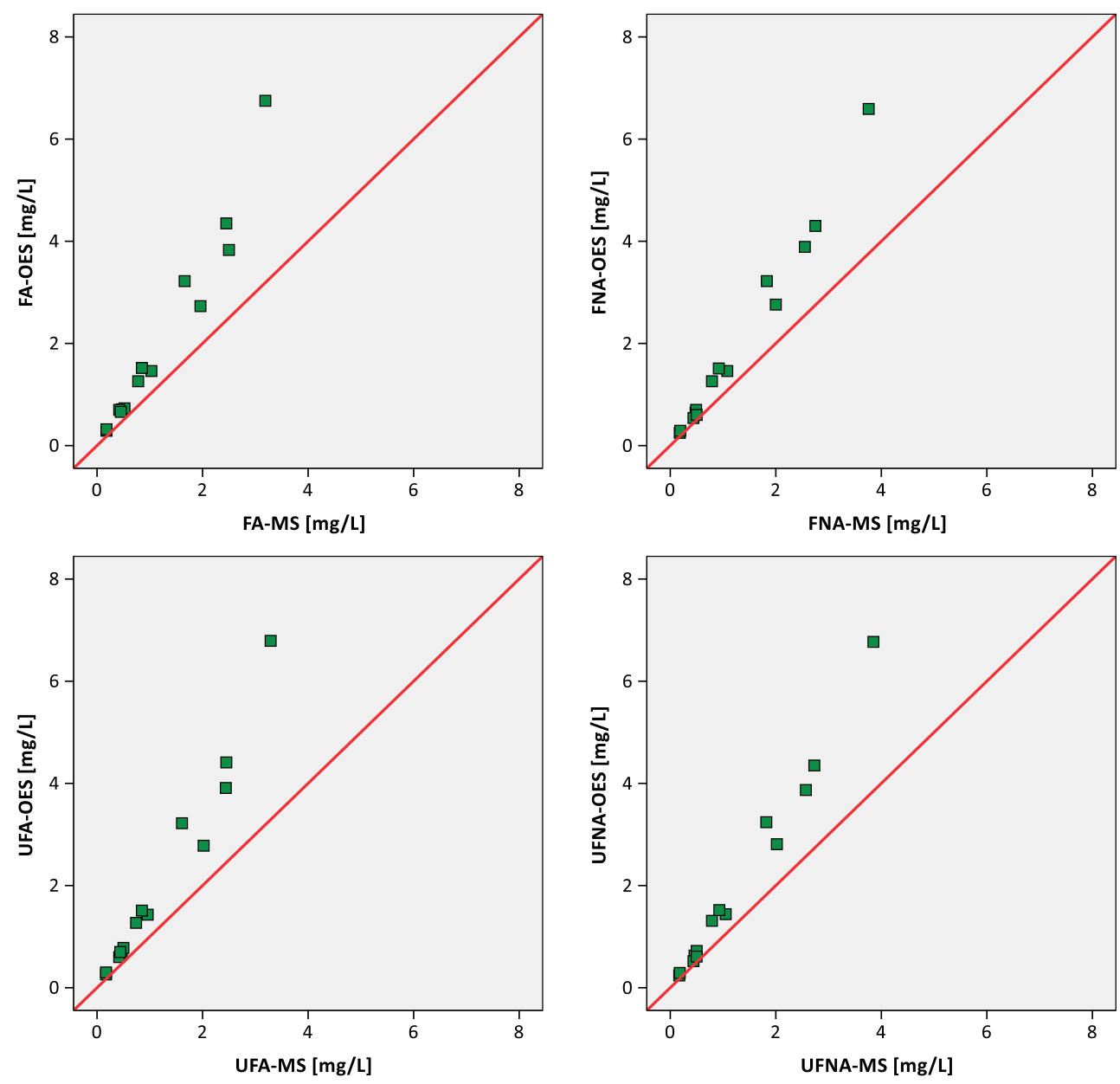
Table 5 Boron concentration in the water samples analysed (correlation of paired samples)

\begin{tabular}{llll}
\hline Sampling protocol/methods of boron determination & Number & Correlation coefficient & Significance \\
\hline FA-MS [mg/L] and FA-OES [mg/L] & 14 & 0.977 & 0.000 \\
FNA-MS [mg/L] and FNA-OES [mg/L] & 14 & 0.993 & 0.000 \\
UFA-MS [mg/L] and UFA-OES [mg/L] & 14 & 0.981 & 0.000 \\
UFNA-MS [mg/L] and UFNA-OES [mg/L] & 14 & 0.993 & 0.000 \\
\hline
\end{tabular}

$F A$ filtered but acidified, $F N A$ filtered but not acidified, UFA unfiltered but acidified, UFNA unfiltered but not acidified

analysis of boron concentration in certified ranges (for ICPMS from 0.01 to $100 \mathrm{mg} / \mathrm{L}$ and for ICP-OES from 0.1 to $100 \mathrm{mg} / \mathrm{L}$ ) gives appropriate results.

The precision of boron determination using both methods is lower than $20 \%$ (estimated as RSD value) whereas accuracy varies from 80 to $120 \%$. An estimate was made of the expanded uncertainty of both the ICP-MS and the ISP-OES methods and did not exceed $20 \%$.

Table 4 summarises the basic descriptive statistics of the results obtained by both methods and using samples prepared differently for each of the analyses.

The mean values of the results obtained by ICP-OES are higher than the means of the results obtained by ICP-MS. Also, the ranges of concentrations of boron obtained by ICP-OES in the samples analysed are greater than those obtained using the ICP-MS method regardless of the method of preparing samples for analysis (Table 4). These differences might be caused by several high-level concentrations in selected whole-water digestates and some matrix effects in the water samples analysed. The research showed that a greater concentration of iron, in concentrations from 1 to $20 \mathrm{mg} / \mathrm{L}$, than chromium $(0.02-1 \mathrm{mg} / \mathrm{L})$ in the water samples analysed can influence boron determination. When iron concentrations are high, we can observe the emission spectrum as double joined with an overlapping peak. This is compatible with the results of a comparison of boron concentrations performed by the Instituto di Geoscienze e Georisorse Area di Ricerca del CNR and International Atomic Energy Agency (IAEA), Vienna, Austria (Gonfiantini et al. 2003).
The results of the boron determination in the water samples tested are also presented on scatterplots (Fig. 1).

The graphs show that the results of boron determinations obtained by both methods have a strong linear correlation. This is confirmed by high values of Pearson correlation coefficients (Table 5). These correlations are statistically significant at $p<0.05$, they are not dependent on the method of sample preparation (sampling protocol).

For boron concentrations less than $1 \mathrm{mg} / \mathrm{L}$, there is a high consistency seen in the results (the points on the graphs are arranged on the diagonal; Fig. 1). At higher concentrations of boron, higher values of the results are achieved in the samples analysed using ICP-OES than in those using ICP-MS.

In order to verify whether the mean values of boron concentration obtained by both methods are statistically significant, a $t$ test was performed for dependent samples (using IBM SPSS v. 21 software). Table 6 summarises the results of this test.

The Mean column displays the average difference between the measurements obtained with the two analytical methods. The Standard deviation column displays the standard deviation of the average difference score. The Standard error mean column provides an index of the variability one can expect in repeated random samples of 14 water samples. The $95 \%$ Confidence interval of the difference provides an estimate of the boundaries between which the true mean difference lies in $95 \%$ of all possible random samples of 14 water samples similar to those analysed. The $t$ statistic is obtained by dividing the mean difference by its standard error; $d f$ means degrees of freedom. The Significance (two-tailed) column displays the

Table 6 Boron concentration in the water samples analysed (paired samples test)

\begin{tabular}{|c|c|c|c|c|c|c|c|c|}
\hline \multirow{3}{*}{$\begin{array}{l}\text { Sampling protocol/methods of boron } \\
\text { determination }\end{array}$} & \multicolumn{5}{|c|}{ Paired differences } & \multirow[t]{3}{*}{$t$} & \multirow[t]{3}{*}{$d f$} & \multirow{3}{*}{$\begin{array}{l}\text { Significance } \\
\text { (two-tailed) }\end{array}$} \\
\hline & \multirow[t]{2}{*}{ Mean } & \multirow[t]{2}{*}{ Std. dev. } & \multirow[t]{2}{*}{ Std. error mean } & \multicolumn{2}{|c|}{$\begin{array}{l}95 \% \text { Confidence interval of the } \\
\text { difference }\end{array}$} & & & \\
\hline & & & & Lower & Upper & & & \\
\hline FA-MS $[\mathrm{mg} / \mathrm{L}]$ and FA-OES $[\mathrm{mg} / \mathrm{L}]$ & -0.85 & 0.965 & 0.258 & -1.4063 & -0.2922 & -3.294 & 13 & 0.006 \\
\hline FNA-MS $[\mathrm{mg} / \mathrm{L}]$ and FNA-OES $[\mathrm{mg} / \mathrm{L}]$ & -0.72 & 0.799 & 0.214 & -1.1802 & -0.2569 & -3.363 & 13 & 0.005 \\
\hline UFA-MS [mg/L] and UFA-OES [mg/L] & -0.86 & 0.967 & 0.258 & -1.4219 & -0.3051 & -3.341 & 13 & 0.005 \\
\hline UFNA-MS $[\mathrm{mg} / \mathrm{L}]$ and UFNA-OES $[\mathrm{mg} / \mathrm{L}]$ & -0.74 & 0.821 & 0.219 & -1.2107 & -0.2621 & -3.354 & 13 & 0.005 \\
\hline
\end{tabular}

$F A$ filtered but acidified, FNA filtered but not acidified, UFA unfiltered but acidified, UFNA unfiltered but not acidified 
Table 7 Impact of filtration and acidification on boron determination in the water samples analysed — differences between the results [mg/L]

\begin{tabular}{|c|c|c|c|c|c|c|c|c|c|c|c|c|c|c|}
\hline \multirow[t]{2}{*}{ Sampling protocol } & \multicolumn{14}{|c|}{ Sample } \\
\hline & 1 & 2 & 3 & 4 & 5 & 6 & 7 & 8 & 9 & 10 & 11 & 12 & 13 & 14 \\
\hline \multicolumn{15}{|l|}{ ICP-MS method } \\
\hline FA-FNA & -0.06 & 0.00 & -0.04 & -0.01 & 0.03 & -0.05 & -0.01 & -0.06 & -0.01 & -0.17 & -0.29 & -0.56 & -0.03 & -0.05 \\
\hline UFA-UFNA & -0.09 & 0.00 & 0.00 & 0.01 & 0.00 & -0.13 & -0.05 & -0.08 & -0.01 & -0.21 & -0.28 & -0.56 & -0.02 & -0.06 \\
\hline FA-UFA & 0.06 & 0.01 & -0.06 & 0.00 & 0.02 & 0.06 & 0.04 & 0.00 & 0.00 & 0.05 & 0.00 & -0.10 & -0.01 & 0.01 \\
\hline FNA-UFNA & 0.03 & 0.01 & -0.02 & 0.02 & 0.00 & -0.02 & 0.00 & -0.01 & 0.01 & 0.01 & 0.01 & -0.10 & 0.00 & 0.00 \\
\hline \multicolumn{15}{|l|}{ ICP-OES method } \\
\hline FA-FNA & 0.06 & 0.04 & 0.02 & 0.07 & 0.01 & 0.00 & 0.00 & 0.07 & 0.05 & 0.17 & 0.35 & 0.72 & 0.19 & 0.11 \\
\hline UFA-UFNA & 0.08 & 0.02 & -0.03 & 0.02 & 0.06 & 0.17 & 0.01 & 0.07 & 0.02 & 0.19 & 0.34 & 0.59 & 0.10 & 0.16 \\
\hline FA-UFA & -0.03 & 0.02 & 0.01 & 0.05 & -0.07 & -0.13 & -0.06 & 0.01 & 0.02 & -0.05 & -0.06 & 0.05 & 0.11 & -0.05 \\
\hline FNA-UFNA & -0.01 & 0.00 & -0.03 & 0.00 & -0.02 & 0.04 & -0.05 & 0.01 & -0.01 & -0.03 & -0.07 & -0.08 & 0.02 & -0.01 \\
\hline
\end{tabular}

FA filtered but acidified, FNA filtered but not acidified, UFA unfiltered but acidified, UFNA unfiltered but not acidified

probability of obtaining a $t$ statistic whose absolute value is equal to or greater than the $t$ statistic obtained.

The table shows that the means of the results obtained by ICP-MS are lower by $0.72-0.86 \mathrm{mg} / \mathrm{L}$ than those obtained by ICP-OES. The means of results obtained by ICP-MS are significantly lower than those obtained by ICP-OES, regardless of the method of sample preparation for analysis (in all cases, significance $<0.05$; Table 6 ).

When analysis is performed within $24 \mathrm{~h}$ of sample collection, - sample filtration and proper preservation is very important. On the basis of the differences presented in Table 7, we can estimate the impact of filtration and acidification on the boron determinations in the water samples analysed using the two methods.

Table 8 Average boron concentrations in the certified samples [mg/L]

\begin{tabular}{llll}
\hline Sampling protocol & $\begin{array}{l}\text { Average boron concentration in certified sample } \\
{[\mathrm{mg} / \mathrm{L}]}\end{array}$ \\
\cline { 2 - 4 } & $\begin{array}{l}0.5 \mathrm{mg} / \mathrm{L} \\
\text { standard }\end{array}$ & $\begin{array}{l}1 \mathrm{mg} / \mathrm{L} \\
\text { standard }\end{array}$ & $\begin{array}{l}2.5 \mathrm{mg} / \mathrm{L} \\
\text { standard }\end{array}$ \\
\hline ICP-MS method & & & \\
FA & 0.495 & 0.997 & 2.662 \\
UFA & 0.505 & 0.985 & 2.688 \\
FNA & 0.479 & 0.934 & 2.477 \\
UFNA & 0.486 & 1.019 & 2.486 \\
ICP-OES method & & & \\
FA & 0.488 & 0.904 & 2.710 \\
UFA & 0.494 & 0.994 & 2.665 \\
FNA & 0.481 & 0.973 & 2.569 \\
UFNA & 0.503 & 0.955 & 2.525 \\
\hline
\end{tabular}

$F A$ filtered but acidified, $F N A$ filtered but not acidified, UFA unfiltered but acidified, UFNA unfiltered but not acidified
For the ICP-MS method, we can observe that the boron concentration in acidified samples is minutely lower than in those nonacidified samples whereas the results for filtered samples are generally greater than for unfiltered samples. The opposite situation can be observed with the ICP-OES method. The results for acidified samples are greater than for the nonacidified water samples whereas filtration caused a decline in boron concentrations in the same water samples (Table 7).

To analyse boron behaviour under different conditions (after filtration and/or acidification), an analysis of samples with known boron concentration was performed. These samples contain boron at three concentration levels: 0.5, 1.0 and $2.5 \mathrm{mg} / \mathrm{L}$.

The results of the comparison of the four sampling protocols tested with average boron concentrations in certified samples are shown in Table 8.

The results of the study show that sample filtration and acidification generally causes a decrease in boron concentration with low concentrations of boron $(0.5$ and $1.0 \mathrm{mg} \mathrm{B} / \mathrm{L})$ whereas in the case of higher concentrations $(2.5 \mathrm{mg} \mathrm{B} / \mathrm{L})$, both filtration and acidification influence the increase in boron concentration in the standard examples analysed. These relations are not dependent on the method of analysis (Fig. 2, Table 8).

In order to verify if the mean values of boron concentration in standard samples obtained by different methods and using different sampling protocols are statistically significant, a $t$ test for dependent samples was performed. Table 9 provides a summary of the results of this test.

The test results of paired samples prove that both sampling and method of analysis influence the boron concentration in the certified samples analysed (Table 9). The differences between the results obtained using the four sampling protocols tested are statistically significant. The results from the ICP- 
Fig. 2 Differences between results obtained during analysis and the true values of boron concentrations in the standard sample - comparison of four sampling protocols and two methods of analysis

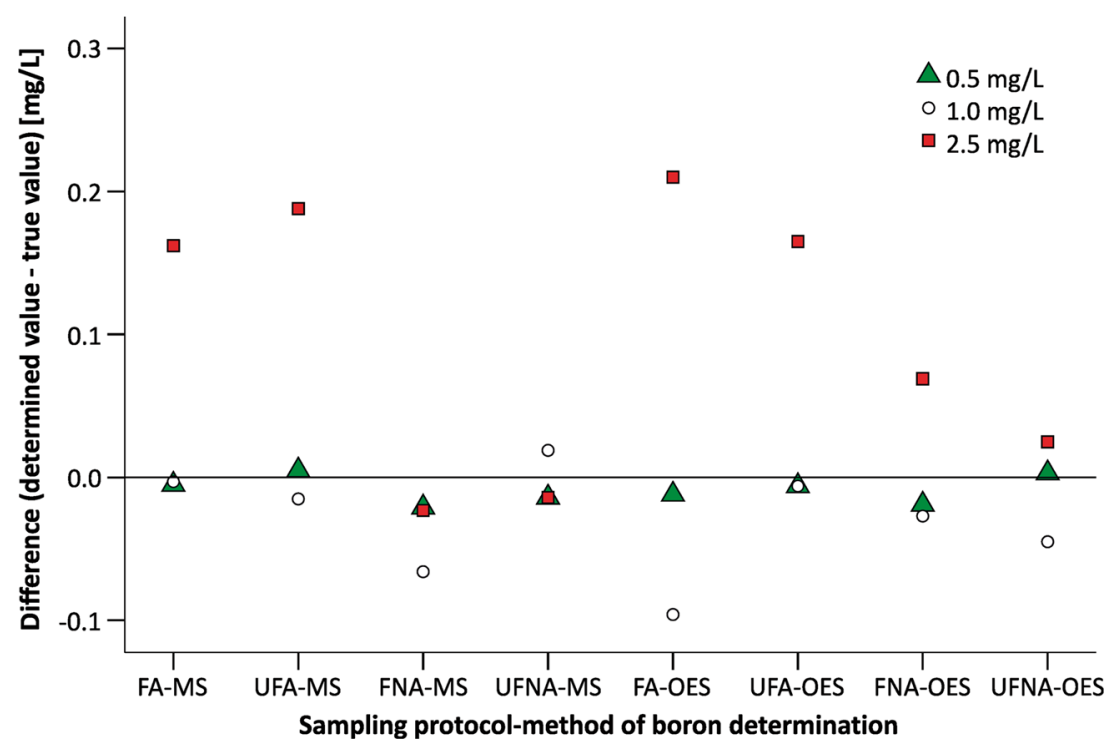

MS method are the most accurate (the analysed value is closer to the true value than with the ICP-OES method). It is necessary to indicate that these differences make a difference of no more than $5 \%$ to the results. It is a lower range than the uncertainty declared by the laboratory for boron analysis. This means that both the ICP-MS and ICP-OES methods can be used for determination of the boron concentration in water.

These results show that the analysis of measurement uncertainty arising from sampling is a very important problem.

\section{Conclusions}

According to the European Standard (EN ISO 5667-3:2012), waters must be filtered on site where the dissolved elements need to be analysed. Membrane filters with a nominal pore size of $0.45 \mu \mathrm{m}$ should be used. Filtration needs to be done as soon as possible after sample collection. Filtration is not necessary for the determination of the total element concentration. Regardless of the form of the elements determined (total or dissolved), all samples for boron analysis should be preserved by the addition of $\mathrm{HNO}_{3}$ to $\mathrm{pH} 1-2$. The same procedure is

Table 9 Boron concentrations in the certified samples (paired samples test)

\begin{tabular}{|c|c|c|c|c|c|c|c|c|}
\hline \multirow[t]{3}{*}{ Sampling protocol/methods of boron determination } & \multicolumn{5}{|c|}{ Paired differences } & \multirow[t]{3}{*}{$t$} & \multirow[t]{3}{*}{$d f$} & \multirow{3}{*}{$\begin{array}{l}\text { Significance } \\
\text { (two-tailed) }\end{array}$} \\
\hline & \multirow[t]{2}{*}{ Mean } & \multirow[t]{2}{*}{$\begin{array}{l}\text { Std. } \\
\text { deviation }\end{array}$} & \multirow[t]{2}{*}{$\begin{array}{l}\text { Std. error } \\
\text { mean }\end{array}$} & \multicolumn{2}{|c|}{$\begin{array}{l}95 \% \text { Confidence interval of the } \\
\text { difference }\end{array}$} & & & \\
\hline & & & & Lower & Upper & & & \\
\hline 0.5 FA-MS-0.5 FA-OES & 0.007 & 0.004 & 0.002 & 0.002 & 0.011 & 3.949 & 4 & 0.017 \\
\hline 0.5 FNA-MS-0.5 FNA-OES & -0.003 & 0.006 & 0.002 & -0.010 & 0.004 & -1.162 & 4 & 0.310 \\
\hline 0.5 UFA-MS-0.5 UFA-OES & 0.011 & 0.005 & 0.002 & 0.004 & 0.017 & 4.504 & 4 & 0.011 \\
\hline 0.5 UFNA-MS-0.5 UFNA-OES & -0.016 & 0.010 & 0.004 & -0.028 & -0.004 & -3.764 & 4 & 0.020 \\
\hline 0.5 FA-MS-0.5 FNA-MS & 0.016 & 0.004 & 0.002 & 0.011 & 0.022 & 8.398 & 4 & 0.001 \\
\hline 0.5 FA-MS-0.5 UFA-MS & -0.010 & 0.005 & 0.002 & -0.016 & -0.004 & -4.673 & 4 & 0.009 \\
\hline 0.5 FNA-MS-0.5 UFA-MS & -0.026 & 0.007 & 0.003 & -0.034 & -0.018 & -8.835 & 4 & 0.001 \\
\hline 0.5 FNA-MS-0.5 UFNA-MS & -0.008 & 0.008 & 0.004 & -0.018 & 0.002 & -2.121 & 4 & 0.101 \\
\hline 0.5 FA-OES-0.5 FNA-OES & 0.007 & 0.005 & 0.002 & 0.001 & 0.013 & 3.259 & 4 & 0.031 \\
\hline 0.5 FA-OES-0.5 UFA-OES & -0.006 & 0.002 & 0.001 & -0.009 & -0.003 & -5.363 & 4 & 0.006 \\
\hline 0.5 FNA-OES-0.5 UFA-OES & -0.013 & 0.004 & 0.002 & -0.018 & -0.008 & -7.093 & 4 & 0.002 \\
\hline 0.5 FNA-OES- 0.5 UFNA-OES & -0.021 & 0.005 & 0.002 & -0.028 & -0.015 & -9.248 & 4 & 0.001 \\
\hline
\end{tabular}

Results obtained with the use of the IBM SPSS Statistics software

$F A$ filtered but acidified, FNA filtered but not acidified, UFA unfiltered but acidified, UFNA unfiltered but not acidified 
required for sample preparation for analysis using the ICP-MS and ICP-OES method (EN ISO 17294-2:2004 and EN ISO 11885:2009).

A total of 56 samples were collected during the different desalination processes: ultrafiltration and a double reverse osmosis system connected in series (Tomaszewska and Bodzek 2013a, 2013b). The authors analysed four sampling protocols:

1. Fourteen samples were filtered (through a membrane filter of $0.45 \mu \mathrm{m}$ ) and acidified (using $1 \mathrm{~mL}$ ultrapure nitric acid for each $100 \mathrm{~mL}$ of samples) (FA)

2. Fourteen samples were unfiltered and not acidified (UFNA)

3. Fourteen samples were filtered but not acidified (FNA)

4. Fourteen samples were unfiltered but acidified (UFA)

All samples were analysed using the ICP-OES and ICPMS methods.

An analysis of the influence of sample filtration and preservation shows that there is a statistically significant difference between the results obtained using the four sampling protocols analysed (Fig. 2). Also, the method of analysis influences the final results of the boron concentrations in water samples. This difference is also statistically significant (Tables 8 and 9, Fig. 1). Generally, the mean values of the results obtained by ICP-OES are higher than the mean values of the results obtained by ICP-MS. Also, the ranges of concentrations of boron in the samples analysed obtained by ICP-OES are greater than those obtained using ICP-MS, regardless of the method of preparing the samples for analysis (Table 5). It is necessary to indicate that these produce differences of no more than $5 \%$ in the results. It is a lower range than the uncertainty declared by the laboratory for boron analysis. This means that the four sampling protocols tested are correct and can be used during boron analysis. For the determination of the dissolved boron concentration, sample filtration in the field is recommended, whereas for determination of the total boron concentration, filtration should be omitted. Sample acidification meant that the boron in the final acidic solution existed as boric acid which is an undissociated and stable form (Al-Ammar et al. 1999). Both the ICP-MS and ICP-OES method can be used for the determination of boron concentrations in water. The differences in boron concentration obtained using these two methods can be caused by several high-level concentrations in selected whole-water digestates and some matrix effects. The presence of more iron (from 1 to $20 \mathrm{mg} / \mathrm{L}$ ) than chromium $(0.02-1 \mathrm{mg} / \mathrm{L})$ in the samples analysed can influence boron determination. When the iron concentration is high, we can observe a double-joined emission spectrum with an overlapping peak.

Acknowledgments This work was financed by the Polish National Centre for Research and Development, grant no. 245079 (2014-2017).
Open Access This article is distributed under the terms of the Creative Commons Attribution 4.0 International License (http:// creativecommons.org/licenses/by/4.0/), which permits unrestricted use, distribution, and reproduction in any medium, provided you give appropriate credit to the original author(s) and the source, provide a link to the Creative Commons license, and indicate if changes were made.

\section{References}

Aggerwal JK, Sheppard D, Mezger K, Pernicka E (2003) Precise and accurate determination of boron isotope ratios by multiple collector ICP-MS: origin of boron in the Ngawha geothermal system, New Zealand. Chem Geol 199:331-342

Al-Ammar A, Gupta RK, Barnes RM (1999) Elimination of boron memory effect in inductively coupled plasma-mass spectrometry by addition of ammonia. Spectrochim Acta B 54:1077-1084

Bodzek M (2015) The removal of boron from the aquatic environmentstate of the art. Desalin Water Treat. doi:10.1080/19443994.2014. 1002281

Bundschuh J, Maity JP, Nath B, Baba A, Gunduz O, Kulp TR, Jean JS, Kar S, Yang HJ, Tseng YJ, Bhattacharya P, Chen CY (2013) Naturally occurring arsenic in terrestrial geothermal systems of western Anatolia, Turkey: potential role in contamination of freshwater resources. J Hazard Mater 262:951-959

Chałupnik S, Franus W, Wysocka M, Gzyl G (2013) Application of zeolites for radium removal from mine water. Environ Sci Pollut Res 20/11:7900-7906

Culver BD, Hubbard SA (1996) Inorganic boron health effects in humans: an aid to risk assessment and clinical judgment. J Trace Elem Exp Med 9:175-184

Dill HG (2010) The "chessboard" classification scheme of mineral deposits: mineralogy and geology from aluminum to zirconium. Earth Sci Rev 100:1-420

Dulski TR (1996) A Manual for the Chemical Analysis of Metals, ASTM Manual Series MNL 25, ISBN 0-8031-2066-4: 1-260

EPA (2008) United States Environmental Protection Agency (EPA) Drinking Water Health Advisory For Boron. U.S. Environmental Protection Agency, Washington, DC, 20460. May, 2008, http:// www.epa.gov/waterscience/

Eppich GR, Wimpenny JB, Yin Q, Esser BK (2011) Californis GAMA special study: stable isotopic composition of boron in groundwateranalytical method development. Final report for the California State Water Resources Control Board. GAMA Special Studies Task 10.4: Development of New Wastewater Indicator Methods. LLNL-TR498360

Farhat A, Ahmad F, Arafat H (2013) Analytical techniques for boron quantification supporting desalination processes. A Rev Desalination 310:9-17

Franus W, Wdowin M (2010) Removal of ammonium ions by selected natural and synthetic zeolites. Mineral Resources Manage 26(4): $133-148$

Franus W, Wdowin M, Franus M (2014) Synthesis of zeolites for fly ash development. Environ Monit Assess 186(9):5721-5729

Garbarino JR (1999) Methods of analysis by the U.S. Geological Survey National Water Quality Laboratory_-determination of dissolved arsenic, boron, lithium, selenium, strontium, thallium, and vanadium using inductively coupled plasma-mass spectrometry: U.S. Geol Survey Open-File Report 31:99-093

Garbarino JR (2000) Methods of analysis by the U.S. Geological Survey National Water Quality Laboratory-determination of whole-water recoverable arsenic, boron and vanadium using inductively coupled plasma-mass spectrometry: U.S. Geol Survey Open-File Report 22: 99-093 
Gonfiantini R, Tonarini S, Gröning M, Adorni-Braccesi A, Al-Ammar AS, Astner M, Bächler S, Barnes R, Bassett RL, Cocherie A, Deyhle A, Dini A, Ferrara G, Gaillardet J, Grimm J, Guerrot C, Krähenbühl U, Layne G, Lemarchand D, Meixner A, Northington DJ, Pennisi M, Reitznerová E, Rodushkin I, Sugiura N, Surberg R, Tonn S, Wiedenbeck M, Wunderli S, Xiao Y, Zack T (2003) Intercomparison of boron isotope and concentration measurements. Part II: Evaluation Results Geostandards Newsletter 27(1):41-57

Kabay N, Güler E, Bryjak M (2010) Boron in seawater and methods for its separation - a review. Desalination 261:212-217

Kmiecik E (2011) Methodological aspects of assessing the chemical status of groundwater. Wyd AGH, Kraków, Polish p. 1-172

Kmiecik E, Podgórni K (2009) Estimation of sampler influence on uncertainty associated with sampling in groundwater monitoring. Biuletyn Państwowego Instytutu Geologicznego 436(9/1):253-260 (in Polish)

Kot FS (2009) Boron sources, speciation and its potential impact on health. Rev Environ Biotehnol 8:3-28

Liu H, Peng S, Shu L, Chen T, Bao T, Frost RL (2010) Effect of $\mathrm{Fe}_{3} \mathrm{O}_{4}$ addition on removal of ammonium by zeolite NaA. J Colloid Interface Sci 390(1):204-210

Malina G (2004) Ecotoxicological and environmental problems associated with the former chemical plant in Tarnowskie Gory, Poland. Toxicology 205:157-172

Merrikhpour H, Jalali M (2013) Comparative and competitive adsorption of cadmium, copper, nickel, and lead ions by Iranian natural zeolite. Clean Techn Environ Policy 15:303-316

Motyka J, Adamczyk Z, Czop M, d'Obyrn K (2005) Groundwater quality impact by municipal sanitary landfill in Ujków near Olkusz (S Poland). Mineral Resources Manage 21(1):131-153

Mr N, Samman S (1993) The role of boron in nutrition and metabolism. Prog Food Nutr Sci 17(4):331-349

Newnham RE (1994) The role of boron in human nutrition. J Appl Nutr 46/3:81-85

Niu Y, Zhao Y, Xi B, Hu X, Xia X, Wang L, Lv D, Lu J (2012) Removal of ammonium from aqueous solutions using synthetic zeolite obtained from coal fly-ash. Fresenius Environ Bull 21(7):1732-1739

Öner SG, Kabay N, Güler E, Kitis M, Yüksel M (2011) A comparative study for the removal of boron and silica from geothermal water by cross-flow flat sheet reverse osmosis method. Desalination 283:1015

Parks JL (2005) Sorption of boron and chromium onto solids of environmental significance: implications for sampling and removal in water treatment. Dissertation, Virginia Polytechnic Institute and State University, Blacksburg, Virginia, pp 1-154

Polat H, Vengosh A, Pankratov I, Polat M (2004) A new methodology for removal of boron from water by coal and fly ash. Desalination 164: $173-188$

Querol X, Umana JC, Plana F, Alastuey A, Lopes-Soler A, Medinaceli A, Valero A, Domingo MJ, Garcia-Rojo E (2001) Synthesis of zeolites from fly ash pilot plant scale. Examples of potential applications. Fuel 80:857-865

Sah R, Brown P (1997) Boron determination - a review of analytical methods. Microchem J 56:285-304
Sah RN, Brown PH (1998) Isotope ratio determination in boron analysis. Biological Trace Element Researchm 66:39-53

Tomaszewska B (2009) Transformations of soil and aquatic environment under the impact of anthropogenic factors - examples from the selected area in Skawina, Rozprawy, Monografie IGSMiE PAN, Nr 158: 101, ISBN 978 -83-60195-97-0

Tomaszewska B, Bodzek M (2013a) Desalination of geothermal waters using a hybrid UF-RO process. Part I: Boron. removal in pilot-scale tests. Desalination 319:99-106

Tomaszewska B, Bodzek M (2013b) The removal of radionuclides during desalination of geothermal waters containing boron using the BWRO system. Desalination 309:284-290

Tomaszewska B, Szczepański A (2014) Possibilities for the efficient utilisation of spent geothermal waters. Environ Sci Pollut Res 21: $11409-11417$

Tomaszewska B, Pająk L, Bodzek M (2014) Application of a hybrid UF$\mathrm{RO}$ process to geothermal water desalination. Concentrate disposal and costs analysis. Archives Environ Protect 40(3):137-151

Turek M, Dydo P, Trojanowska J, Campen A (2007) Adsorption/co-precipitation - reverse osmosis system for boron removal. Desalination 205:192-199

van de Wiel HJ (2003) Determination of elements by ICP-AES and ICPMS. National Institute Public Health Environ (RIVM). 1-37

Wdowin M, Franus M, Panek R, Badura L, Franus W (2014) The conversion technology of fly ash into zeolites. Clean Techn Environ Policy 16(6):1217-1223

WHO (2011), World Health Organization (WHO), Guidelines for Drinking-water Quality. Fourth edition. www.who.int, 2011, ISBN 9789241548151

Witczak S, Szklarczyk T, Kmiecik E, Szczepańska J, Zuber A, Różański K, Duliński M (2007) Hydrodynamic modelling, environmental tracers and hydrochemistry of a confined sandy aquifer (Kędzierzyn-Głubczyce Subtrough, SW Poland). Geol Quarter 51(1):1-16

Witczak S, Kania J, Kmiecik E (2013) Katalog wybranych fizycznych i chemicznych wskaźników zanieczyszczeń wód podziemnych i metod ich oznaczania. Inspekcja Ochrony Środowiska. Biblioteka Monitoringu Środowiska, Warszawa, in Polish. ISBN 978-8361227-13-7

Witkowski A, Kowalczyk A, Rubin H, Rubin K (2008) Groundwater quality and migration of pollutants in the multi-aquifers system of the former chemical works "Tarnowskie Góry" area. Polish Geological Institute Special Papers 24:123-130

Wolska J, Bryjak M (2013) Methods for boron removal from aqueous solutions - A review. Desalination 310:75-80

Woods W (1994) An introduction to boron: history, sources, uses, and chemistry. Environ Health Perspect 102:5

Yavuz E, Arar Ö, Yüksel M, Yüksel Ü, Kabay N (2013) Removal of boron from geothermal water by $\mathrm{RO}$ system-II-effect of $\mathrm{pH}$. Desalination 310:135-139

Yüksel S, Yürüm Y (2010) Removal of boron from aqueous solutions by adsorption using fly ash, zeolite, and demineralized lignite. Sep Sci Technol 45(1):105-115 